\title{
The Healthcare Providers-Patients Relationship and State Obligations in Times of Public Health Emergency
}

\author{
Gloria C. Nwafor
}

School of Law, University of Venda, South Africa

\author{
Anthony O. Nwafor
}

University of Venda, Thohoyandou, South Africa

drtonynwafor@yahoo.com

\begin{abstract}
The recent outbreak of Ebola Virus Disease (EVD) in the West African sub-region sprung challenges on the healthcare providers in the observance of their ethical rules in dealing with their patients and the State in fulfilling its obligations to ensure that the rights of patients are respected in times of public health emergency. The ethical rules of medical practice demand that the healthcare providers prefer the interests of their patients to the preservation of self. The State is by law under obligation to protect and respect the rights of the patients in all situations. The paper argues that the responses by the healthcare providers and the States in the West African sub region in the wake of the public health emergency fell short of the demands of the ethical rules of the medical profession and the obligation to ensure that the rights of the patients are respected.
\end{abstract}

\section{Keywords}

Healthcare - Emergency - Healthcare provider - Patient - Ethics - State - Human rights

* The first author is grateful to Prof. G. N. K Vukor-Quarshie and Ms P. P. Letuka who were the supervisors of her postgraduate work at the University of Venda the outcome of which formed the foundation of this article. 


\section{Introduction}

The eternal obligation of healthcare providers to their patients has always been, from time immemorial, to place the wellbeing of the patient ahead of that of self. The basis of that obligation is traced to the oath of medical practice which demands utmost selfless service and confidentiality from the healthcare providers in their relationships with their patients. This relationship which evolved as mere rule of ethics has now metamorphosed into issues of human rights and are protected by the various national and international instruments. The level of compliance by the healthcare providers with this obligation is often tested in the occasion of public healthcare emergency. The recent incidence of the spread of Ebola Virus Disease (EVD), a highly infectious disease, in some West Africa nations including Nigeria, Liberia, Sierra Leone and Guinea, which left on its trail a significant number of human casualties sprung questions about the level of compliance by healthcare providers with obligations to their patients in occasions of public healthcare emergency. The preference for the preservation of self over that of the patients which seemingly prevailed among the healthcare providers in the West African nations raises questions about the compliance with the ethical rules of medical practice and respect for the human rights of patients in times of public health emergency. The importance of the observation of the ethical rules and preservation of the human rights of patients are emphasized as the only guarantees of fair disclosure of the existence and causes of infections by the patients to the healthcare providers. Failure to fulfil that obligation has the tendency to drive the patient underground and invariably escalating rather than mitigating the spreading of the disease. The paper examines the relationship between the healthcare providers and their patients and discusses the need for the protection of the human rights of the patient as vital measures to controlling of the spread of infection under public health emergency.

\section{2 Physician-Patient Relationship}

From ancient times, physicians have recognized that the health and wellbeing of patients depend upon a collaborative effort between physician and the patient. Patients share with physicians the responsibility for their own healthcare. The patient-physician relationship is of greatest benefit to the patients when they bring medical problems to the attention of their physicians in a timely fashion, provide information about their medical condition to the 
best of their ability, and work with their physician in a mutual alliance. ${ }^{1}$ The physician-patient relationship is central to the practice of healthcare and is essential for the delivery of high-quality healthcare in the diagnosis and treatment of disease. ${ }^{2}$ The relationship of a physician and a patient is based on trust and gives rise to physician's ethical obligation to place patient's welfare above his/her own self-interest, and above interests of any other person(s), and to promote the patient's welfare. It is the type of relationship described as fiduciary. ${ }^{3}$

Defining the term fiduciary is problematic because a definition cannot capture all the subtleties of fiduciary responsibility. In Bristol and West Building Society $v$ Mothew ${ }^{4}$ Millett LJ defined a fiduciary as "someone who has undertaken to act for or on behalf of another in a particular matter in circumstances which give rise to a relationship of trust and confidence." The central idea is that a fiduciary is an actor who is "required to look after the interest(s) of ... others with vigilance, dedication and selflessness. ${ }^{5}$ Fiduciary duty entails abnegation, that is, both loyalty and selflessness. ${ }^{6}$ Within the scope of fiduciary undertakings, fiduciary duty negates the ordinary freedom of fiduciary actors to pursue self-interest. In Mothew's case Millett LJ emphasised that:

1 'Opinion 10.01-Fundamental Elements of the patient-Physician Relationship' available at www.ama-assn.org/ama/pub/physician.../medical.../opinionıoo.page (accessed 4 February 2015); The patients' satisfaction with an encounter with healthcare services is mainly dependent on the duration and efficiency of care, and how empathetic and communicative the healthcare providers are. It is favoured by a good physician-patient relationship. Also, patients who are well informed of the necessary procedures in a clinical encounter, and the time it is expected to take, are generally more satisfied even if there is a longer waiting time. See Michael Pulia 'Simple Tips to Improve Patients Satisfaction' (2011) 18 (1) American Academy of Emergency Medicine 18-19.

2 'Doctor-patient relationship' available at http://en.wikipedia.org/wiki/Doctor\%E2\%80\%93 patient_relationship (accessed 14 January 2015).

3 SB Odunsi and AO Nwafor 'Medical Confidentiality: Right of HIV/AIDs Patient and the Third Party Interest' (2006) 16 (2) Lesotho Law Journal 250.

4 [1998] Ch 1 at 18A.

5 Moe Litman, 'Fiduciary law in the hospital context: the prescriptive duty of protective intervention' (2007) Vol 15 Health Law Journal 299. See also Bristol and West Building Society v Mothew [1998] Ch 1 at 18A; Ultraframe (UK) Ltd v Fielding [2005] EWHC 1638 (Ch) para 1300. In Extrasure Travel Insurance Ltd v Scattergood [2003] 1 BCLC 598 at 617 Mr Jonathan Crow QC stated that fiduciary duties are concerned with concepts of honesty and loyalty and not with competence.

6 Abnegation is defined as renunciation of one's interest in favour of the interest of another. See The Free Dictionary, available at www.thefreedictionary.com/abnegation (accessed 3 February 2015). 
The various obligations of a fiduciary merely reflect different aspects of his core duties of loyalty and fiduciary. Breach of fiduciary obligation, therefore, connotes disloyalty or infidelity. Mere incompetence is not enough. A servant who loyally does his incompetent best for his master is not unfaithful and is not guilty of a breach of fiduciary duty. ${ }^{7}$

In order for the physician to make accurate diagnosis and provide optimal treatment recommendation, the patient must communicate all relevant information about disease or ailment. This may require the disclosure of sensitive information, which would be embarrassing or harmful if it were known to other persons. The promise of confidentiality permits the patient to trust that information revealed to the physician will not be further disseminated. The expectation of confidentiality derives from the public oath which the physician has taken, and from the accepted code of professional ethics. ${ }^{8}$ Physicians are ethically obliged to refrain from divulging to third parties information which their patients have passed to them in confidence. ${ }^{9}$

\section{Medical Ethics and the Law}

Medicine is a highly regulated profession practiced by men and women of untrammeled intellectual esteem who enjoy the unequivocal confidence of their patients. The quest to curtail abuses of such confidence and to ensure optimal exercise of dexterity by the physician in the care for his or her patient necessitated the formulation of some moral code of conduct, some of which have over the years metamorphosed into rules of law, to serve as guides in directing the services of the physician to his or her patient. ${ }^{10}$ These bodies of moral rules are simply referred to as the ethics of the profession or rules of professional conduct. The earliest of such medical ethics is embodied in a statement attributed to a great physician, Hippocrates, who in present times is referred to as the

7 Mothew's case (note 4 supra) $18 \mathrm{E}-\mathrm{F}$.

8 JO Mary Ludwing and Wylie Burke 'Physician-Patient Relationship' University of Washington School of Medicine, Ethics in Medicine available at http://depts..washington .edu/bioethx/topics/physpt.html (accessed 14January 2015).

9 Odensi \& Nwafor (note 3 supra) 250.

10 Anthony O. Nwafor 'Comparative perspectives on euthanasia in Nigeria and Ethiopia' (2010) 18 (2) African Journal of International and Comparative Law 178. 
father of modern medicine, and whose statement is administered as an Oath to practitioners of medicine. ${ }^{11}$ The Hippocratic Oath states in part as follows:

I swear ... that, according to my ability and judgment, I will keep this Oath and this contract: ... Into whatever homes I go, I will enter them for the benefit of the sick, avoiding any voluntary act of impropriety or corruption, .... Whatever I see or hear in the lives of my patients, whether in connection with my professional practice or not, which ought not to be spoken of outside, I will keep secret, as considering all such things to be private. So long as I maintain this Oath faithfully and without corruption, may it be granted to me to partake of life fully and the practice of my art, gaining the respect of all men for all time. However, should I transgress this Oath and violate it, may the opposite be my fate. ${ }^{12}$

The World Medical Association has made some modifications to this Oath to bring it in line with the practice and language of modern medicine but without losing the precepts. The modified version, otherwise referred to as the Geneva Declaration of 1949, enjoins the physician to maintain utmost respect for human life from time of conception, even under threat, and not to use his medical knowledge contrary to the laws of humanity.13

Healthcare providers operate on a foundation of ethical principles, namely beneficence (doing good), non-maleficence (do no harm), and justice (just distribution of finite resources). ${ }^{14}$ Beneficence is the most prominent principle that comes into play in considering treatment of patients in times of public health emergency. It refers to a provider's duty to help patients, so long as the patient's initial complaint falls within the provider's scope of practice..$^{15} \mathrm{~A}$ healthcare provider has an ethical and professional duty to address a patient's needs, as long as the patient's diagnosis or when the patient's initial complaint, on the face of it, falls within the provider's scope of practice. ${ }^{16}$ Refusing to do so is not consistent with the ethical principle of beneficence. The risk of

\footnotetext{
11 Ibid.

12 'The Hippocratic Oath' available at http://www.nlm.nih.gov/hmd/greek/greek_oath.html (accessed 18 April 2015).

13 Nwafor (note 11 supra) 179.

14 Are Healthcare Providers Legally Obligated to Treat Ebola Patients? available at http:// midlevelu.com/blog/are-healthcare-providers-legally-obligated-treat-ebola-patients (accessed 19 Apria 2015).

15 Ibid.

16 VL Hood, 'Can a physician refuse to help a patient? American perspective'(2008) 118 (6) Pol Arch Med Wewn 368-372.
} 
disease transmission, the grounds on which healthcare providers are most likely to refuse to treat patients suffering from infectious disease, does not preclude healthcare providers from the principle of beneficence. Under this ethical medical principle, healthcare providers are obligated to treat patients suffering from infectious disease. ${ }^{17}$ The basis of ethics, according to Swami Vivekananda, is to become more and more selfless: "[w]hether men understand it or not, they are impelled by that power behind to become unselfish. That is the foundation of morality. It is the quintessence of all ethics, preached in any language, or any religion, or by any prophet in the world. Be thou unselfish", Not 'I', but "Thou - that is the background of ethical codes." 18

In the wake of the recent outbreak of Ebola Virus Disease (EVD) in the West African nations, healthcare providers were reported to have abandoned the victims in preference for the preservation of their own lives. Respite only came to the victims with the intervention of mostly international volunteer organisations some of whose personnel actually paid with their lives to save the Ebola victims. ${ }^{19}$ Some reasons have been adduced as to why healthcare providers may prefer their own interests to that of the patients, obviously in disregard of ethics, among which are that: (i) a large initial investment is required to set up a clinic, a hospital or a medical institute; and it is thought appropriate to charge heavy fees from the patients as a means of recovering the cost; (ii) increased awareness in the patient community about their legal rights. Thus, doctors are conscious of the legal implications of any negligence in treating the patients. Where actions are instituted by the patients, legal fees to be paid by the doctor could be substantial and hence the hospital charges are high; (iii) the patient approaches a doctor with mixed feeling of faith and fear, of hope and hostility. This inevitably leads to distorted doctor-patient relationship with high chances of exploitation; (iv) many doctors do not (or cannot) offer the best line of treatment to the patients; (v) some doctors are ill-trained.

17 'Are Healthcare Providers Legally Obligated to Treat Ebola Patients?' available at http:// www.midlevelu.com/blog/are-healcare-providers-legally-obligated-treat-ebola-patients (accessed 4 February 2015). See also 'The Hippocratic Oath' available at www.med.uottawa .ca/students/md/.../eng/hippocratic_oath.html (accessed 25 March 2015). The primary standard of care for all healthcare professionals is the delivery of high quality care to everyone, regardless of underlying disease, failure to do so is a potential breech of medical ethics, available at http://health.ri.gov/publications/briefs/20141007Professional ResponsibilitiesForTreatmentOfPatientsWithEbola.pdf (accessed 7 February 2015).

18 C S Shah, 'Revival of medical Ethics' available at www.boloji.com/index.cfm?md=Content\& $s d=$ Articles\&ArticleID (accessed 4 February 2015).

19 'Should doctors "have" to treat Ebola patients?' - AMERICAblog, available at americablog. com/2014/og/doctors-treat-ebola-patients.html (accessed 24 March 2015). 
They themselves are not fully aware of recent advances in the treatment and management of the disease; and (vi) many doctors do not have standard treatment facilities in their own clinics or hospitals. Although some of these reasons may seem significantly compelling, they are not sufficient to override the underlying ethical obligation of the physician which is selfless service to the patient.

Patient care refers to the prevention, treatment, and management of illness and the preservation of physical and mental well-being through services offered by health professionals. ${ }^{20}$ More specifically, patient care consists of services rendered by healthcare professionals (or non-professionals under their supervision) for the benefit of patients. ${ }^{21}$ Patient care is a discrete and important aspect of the right to healthcare that merits attention and scrutiny as a human right issue. ${ }^{22}$

Human rights in patient care refers, not just to entitlements for actual patients, but to legal, ethical, and human rights standards in the provision of care that concern health providers and the entire community. ${ }^{23}$ Apart from the ethical standard which demands that healthcare providers should place the interests of the patient above personal interests, it is internationally recognised that patients are by law entitled to some basic empowerment rights such as information, consent, free choice, privacy and confidentiality, rights to a remedy for abuses, and rights of access to services, in the course of their dealings with the healthcare providers. ${ }^{24}$ These components of human rights constitute a critical part of the provision of quality and appropriate healthcare aimed at attaining the highest standard of health.

20 'Patient care - definition of Patient care by Medical dictionary' available at medicaldictionary.thefreedictionary.com/Patient+care (accessed 21 January 2015).

21 'Health and Human Rights Resource Guide' Harvard School of Public Health: Harvard University, available at http://hhrguide.org/wp-content/uploads/sites/25/2014/o3/ HHRRG-master.pdf (accessed 12 January 2015).

22 Jonathan Cohen and Tamar Ezer 'Human Rights in Patients Care: A Theoretical and Practical Framework'(2015) 15(2) Health and Human Rights 7.

23 'Health and Human Rights' A Resource Guide for the Open Society Institute and Soros Foundations Network June 2007, available at http://kelinkenya.org/wp-content/up loads/2010/10/Health-and-Human-Rights-Resource-Guide-OSI-Equitas.pdf (accessed 25 January 2015).

24 Ibid. 
The call for the protection of patients' rights is a movement that is growing globally to make governments and healthcare providers more accountable for providing access to quality healthcare services. ${ }^{25}$ Patients' rights are an integral component of human rights. They promote and sustain beneficial relationships between patients and healthcare providers. The role of the patients' rights therefore is to reaffirm fundamental human rights in the healthcare context by according patients humane treatment. The need to protect and promote the dignity, integrity, and respect of all patients is now widely accepted. ${ }^{26}$ To this end, the World Health Organisation (wHO) predicts that the articulation of patients' rights will in turn make people more conscious of their responsibilities when seeking and receiving or providing healthcare. This will ensure that patient-provider relationships are marked by mutual support and respect. ${ }^{27}$

Patients' rights vary in different countries and in different jurisdictions, often depending upon prevailing cultural and social norms. Different models of the patient-physician relationship - which can also represent the citizenstate relationship - have evolved. These have informed the particular rights to which patients are entitled. In North America and Europe, for instance, there are at least four models which depict this relationship, namely: the paternalistic model, the informative model, the interpretive model, and the deliberative model. Each of these suggests different professional obligations of the physician toward the patient. For instance, in the paternalistic model, the best interests of the patient as adjudged by the clinical expert are valued above the provision of comprehensive medical information and decision-making power to the patient. The informative model, by contrast, sees the patient as a consumer who is in the best position to judge what is in his/her own interest, and thus views the doctor as chiefly a provider of information. There continues to be enormous debate about how best to conceive of this relationship, but there is also growing international consensus that all patients, including those suffering from infectious disease, have rights to privacy, to the confidentiality

25 'Health and Human Rights' A Resource Guide for the Open Society Institute and Soros Foundations Network June 2007 available at http://kelinkenya.org/wp-content/ uploads/2010/10/Health-and-Human-Rights-Resource-Guide-OSI-Equitas.pdf (accessed 25 January 2015).

26 Benson Oduor Ojwang, Emily Atieno Oguta and Peter Maina Matu 'Nurses' impoliteness as an impediment to patients' rights in selected Kenyan hospital' (2010) 12 (2) Health And Human Rights 101.

27 Karima Ahmed Elsayed, Omebrahiem A El-Melegy and Amaal M El-Zeftawy 'The Effect of an Educational Intervention on Nurses' Awareness about Patients' Rights in Tanta' (2013) 9(9) Journal of American Science 211. 
of their medical information, to consent to or to refuse treatment, and to be informed about relevant risk to them of medical procedures. ${ }^{28}$

A vast and severe range of human rights violations occur in the process of patients care. In response to the growing concerns about these abuses of patients' rights in many parts of the world, the concept of 'human rights in patient care' evolved as a framework for monitoring healthcare providers, analysing abuses and holding accountable the violators of such rights. ${ }^{29}$ Respect for patient's dignity and autonomy are the keys to a cordial relationship between the healthcare provider and the patient.

\section{Patients Care and Right to Dignity}

Human dignity refers to one's self-esteem, self-regard and self-respect. Dignity is concerned with how individuals feel, think and behave in relation to the worth or value of themselves and others. To treat persons with dignity is to treat them as being of worth, in a way that is respectful of their diversity, as valued individuals. ${ }^{30}$ When a person's dignity is interfered with, the person feels degraded, embarrassed and humiliated..$^{31}$ On the contrary, when dignity is respected persons feel in control, valued, confident, comfortable and able to make decisions for themselves. ${ }^{32}$ In healthcare situations, dignity may be promoted or diminished by the physical environment; organisational culture; by the attitudes and behaviour of healthcare providers and others and by the way in which care activities are carried out. Healthcare providers are under obligation to treat all patients in all settings and of any health status with dignity, and dignified care should continue after death. ${ }^{33}$

The Universal Declaration of Human Rights was pivotal in popularising the use of 'dignity' or 'human dignity' in human rights discourse. ${ }^{34}$ The importance

28 'WHO| Patients rights' available at http://www.who.int/genomics/public/patientrights/ en/ (accessed 23 January 2015).

29 Jonathan Cohen (note 22 supra) 7.

30 Dignity and me - RCN, available at www.rcn.org.uk > ... > CPD online learning > Dignity in health care (accessed 27 January 2015).

31 Annabel Burt 'What is the relationship between human rights and human dignity' available at www.peterjepson.com/law/CIT2-6\%20Burt.pdf (accessed 14 April 2015).

32 Dignity and me - RCN www.rcn.org.uk > ... > CPD online learning > Dignity in health care (accessed 27 January 2015).

33 Ibid.

34 Christopher McCrudden 'Human Dignity and Judicial Interpretation of Human Rights' (2008) Vol 19 Issue 4 European Journal of International Law 655-724. 
of respect for human dignity as a human right draws from the events proceeding and up to the Second World War where millions of Jews were used for human experiment, tortured and killed by agents of Adolf Hitler. The world was alarmed by the horrendous dehumanisation of humanity in the torture chambers created by Hitler. This galvanised global action leading to the recognition of the need for the protection of human dignity by the United Nations. ${ }^{35}$

The Un Universal Declaration of Human Rights which embodies a universally accepted framework for the protection of human rights recognizes that the inherent dignity and the equal and inalienable rights of all members of the human family are the foundations of freedom, justice and peace in the world. Article 1 of the Universal Declaration states that all human beings are born free and equal in dignity and in rights. ${ }^{36}$ The Universal Declaration links dignity with other fundamental rights. Article 22 provides that everyone, as a member of society, has the right to social security and is entitled to realization, through national effort and international co-operation and in accordance with the organisation and resources of each State, of the economic, social and cultural rights indispensable for his dignity and the free development of his personality.

Various other international and national human rights instruments have followed the lead by the Universal Declaration in upholding the inextricable relationship between human rights and human dignity. The International Convention on Economic, Social and Cultural Rights (ICESCR) states in its preamble that human rights derive from the inherent dignity of the human person. The International Convention on Civil and Political Rights (ICCPR) recognizes that all human rights derive from the inherent dignity of the human person. Article 10 of the ICCPR provides that all persons deprived of liberty shall be treated with humanity and with respect for the inherent dignity of the human person. The African Charter on Peoples and Human Rights (ACPHR) contains provisions recognizing the right to dignity in article 5 which states that every individual shall have the right to the respect of the dignity inherent in a human being and to the recognition of his legal status. All forms of exploitation and degradation of man, particularly slavery, slave trade, torture, cruel, inhuman or degrading punishment and treatment shall be prohibited. The constitutions of Nigeria, Serra Leone, Liberian and Guinea, respectively recognize the inherent dignity of the human person. Section 34(1) of the Nigerian Constitution of 1999

\footnotetext{
35 Annabel Burt 'What is the relationship between human rights and human dignity' available at www.peterjepson.com/law/CIT2-6\%20Burt.pdf (accessed 14 April 2015).

36 Universal Declaration of Human Rights, General Assembly Resolution 217A(111) 10th December 1948.
} 
specifically provides that every individual is entitled to respect for the dignity of his person, and as such prohibits the subjecting of individuals to torture or to inhuman or degrading treatment; slavery or servitude; and to perform forced or compulsory labour. ${ }^{37}$ The constitution of the Republic of Guinea, 2010 bears a more positive pronouncement on the dignity of human person. Article 5 of the Constitution declares that "[t]he human person and their dignity are sacred. The State has the duty to respect them and to protect them."38

Although the constitutions of Sierra Leone and Liberia respectively did not expressly use the word 'dignity' in their provisions, the prohibitions of torture, inhuman and degrading treatment as provided in those constitutions are obviously aimed at the protection of human dignity. Inferences could be drawn from the South African courts pronouncements to buttress this point. In $S v$ Makwanyane ${ }^{39} \mathrm{O}$ Regan J stated that " $\left.\mathrm{r}\right]$ ecognising a right to dignity is an acknowledgement of the intrinsic worth of human beings: human beings are entitled to be treated as worthy of respect and concern. This right therefore is the foundation of many of other rights that are specifically entrenched [in the Bill of Rights]". In Le Roux and Others v Dey ${ }^{40}$ Harms DP observed that:

The term 'dignity' covers a number of concepts in ... the Constitution, but in the present context we are concerned with the plaintiff's sense of selfworth. Melius de Villiers spoke of inborn right to the tranquil enjoyment of one's peace of mind and the valued serene condition in one's social or individual life which has been violated when one is subjected to offensive and degrading treatment, or exposed to ill-will, radicle, disesteem or contempt.

In the consolidated cases of Dawood and Another $v$ Minister of Home Affairs and Others, Shalabi and Another $v$ Minister of Home Affairs and Others, Thomas and Another $v$ Minister of Home Affairs and Others ${ }^{41}$ Corbett CJ stated that under the South Africa constitutional order, the recognition and protection of human dignity is the foundational constitutional value. Descending to the

37 Similar provisions are contained in ss 19 and 20 of the Sierra Leonean Constitution of 1991, and article 12 of the Liberian Constitution, 1986.

38 See also article 6 of the Constitution which prohibits torture, inhuman and degrading treatment. 
inhuman treatment of the black population during the apartheid era, the judge observed that:

The value of dignity in our constitutional framework cannot ... be doubted. The Constitution asserts dignity to contradict our past in which human dignity for black South Africans was routinely and cruelly denied. It asserts it too to inform the future, to invest in our democracy respect for the intrinsic worth of all human beings. Human dignity therefore informs constitutional adjudication and interpretation at a range of levels.

Dignity has thus been described as the grundnorm of the South African Constitution. ${ }^{42}$ Patients have equal worth as every other human being irrespective of the nature of the disease which the patient is afflicted. They should be treated as persons able to feel, think and behave in relation to their own worth or value. Victims of infectious disease should not be treated as outcasts in the society. In the wake of the outbreak of EVD in the West African nations, a victim was shown being conveyed in a wheel barrow and some were abandoned at make-shift healthcare centre without medical care. Such conducts constitute acts of infringement on the victims' right to dignity. ${ }^{43}$ It behooves on the healthcare providers to ensure that the dead are buried with dignity and not cast into the 'evil forest' as accursed persons or dumped in the streets to be fed upon by mammals.

\section{Patient Care and the Right to Information}

The right to information is an internationally recognised human right. It applies to every person who seeks to receive or impart information on a subject matter of interest. The ICCPR recognizes the right to information in article 19(2) which provides that everyone shall have the right to freedom of expression; this right shall include freedom to seek, receive and impart information

42 See Druccila Cornell, Stu Woolman, Sam Fuller, Jason Brickhill, Michael Bishop and Diana Dunbar, The Dignity Jurisprudence of the Constitutional Court of South Africa Vol I (New York, Fordam University Press, 2013) 7.

43 Man transports a possible victim of the Ebola virus in a wheelbarrow on Thursday at the Ebola treatment center at Island Hospital in Monrovia, Liberia. (Oct 2, 2014), available at http://earthsquare.net/7759 (accessed 15 May 2015); See also Ebola Patients Abandoned, Health Team Down Tools-Health-Nairaland' available at http://www.naira land.com/1862229/ebola-patients-abondoned-health-team (accessed 9 September 2014). 
and ideas of all kinds, regardless of frontiers, either orally, in writing or in print, in the form of art, or through any other media of his choice. In relation to women, article $10(\mathrm{~h})$ of the Convention on the Elimination of all Forms of Discrimination Against Women (CEDAW) 1979 enjoins state parties to provide access to specific educational information to ensure the health and well-being of families, including information and advice on family planning. Article 9(1) of the ACHPR provides that every individual shall have the right to receive information. More specific provisions on health related information are found in the Convention on Human Rights and Biomedicine which provides in article 10(2) that everyone is entitled to know any information collected about his or her health. ${ }^{44}$ The World Medical Association's Declaration of Lisbon on Rights of the Patient (Lisbon Declaration) states that the patient has the right to receive information about himself/herself recorded in any of his/her medical records, and to be fully informed about his/her health status including the medical facts about his/her condition. ${ }^{45} \mathrm{~A}$ patient's right to be informed constitutes an essential part of healthcare accessibility. ${ }^{46}$

In many cases, patients, except perhaps the few enlightened ones, are unaware of their rights, including the right to information on their health conditions and the right to access their medical records. The healthcare providers who are motivated by financial gains are not always disposed to providing information to the patients on reasonable treatment options, the available alternatives and the likely benefits and risks of proposed treatment and nontreatment. In $\mathrm{KH}$ and Others $v$ Slovakia ${ }^{47}$ the applicants who could not conceive after consultations with the gynaecologists hospitals suspected that they were sterilised and demanded for their medical records. The hospitals refused to release their medical records to their authorised legal representatives or to

44 Convention for the Protection of Human Rights and Dignity of the Human Being with regard to the Application of Biology and Medicine: Convention on Human Rights and Biomedicine Oviedo, 4.IV.1997, available at http://conventions.coe.int/Treaty/en/ Treaties/Html/164.htm (accessed 25 April 2015).

45 The Declaration of Lisbon was adopted in 1981 by the 34th World Medical Assembly at Lisbon. The preamble states that while a physician should always act according to his/her conscience, and always in the best interests of the patient, equal effort must be made to guarantee patients autonomy and justice. This Declaration represents some of the principal rights of the patient that the medical profession endorses and promotes, available at http://www.wma.net/en/3opublications/1opolicies/l4/ (accessed 25 April 2015). (The Declaration of Lisbon).

46 See Un Committee on Economic, Social and Cultural Rights (CESCR) General Comment No 14 para 12.

App. No. 32881/04 (ECtHR) (April 28, 2009). 
allow them to obtain copy of the documents. The European Court held that the hospitals refusal amounted to a violation of the rights of the women to information and access to justice.

Similarly, in Roche $v$ United Kingdom ${ }^{48}$ the defence establishment had conducted a research into chemical weapons for the UK's armed forces, including tests of gases on humans and animals. The applicant, a serviceman, complained that he was not given adequate information about the tests performed on him. The Court found that the State has not fulfilled the positive obligation to provide an effective and accessible procedure enabling the applicant to have access to all relevant and appropriate information that would allow him to assess any risk to which he had been exposed during his participation in the tests.

There is ongoing debate in the medical field on the extent of information which a physician is required to disclose to the patient. This is premised on the fact that consent of the patient is required before administering treatment, and consent cannot be real without adequate information. Pattinson observed that it would be impractical for the law to require a doctor to disclose all the known risks of a procedure to all patients. A patient is not usually in a position to understand or absorb all that information, or resolve conflicts in professional opinion. Conversely, a patient who knows nothing about a procedure cannot be said to have consented to it. The law requires something between these two extremes. ${ }^{49}$ Brazier suggests that within a reformulated fiduciary relationship "the doctor's duty would be to make available to the patient that information that it seems likely that individual patients would need to make an informed choice on treatment." 50

The judiciary has descended into the arena of this debate. In Chatterton $v$ Garson $^{51}$ Bristow J held that once the patient is informed in broad terms of the nature of the procedure which is intended, and gives his consent, that consent is real. In Sidewayv Bethlem Royal Hospital ${ }^{52}$ the House of Lords held that a doctor need only disclose such information as would be disclosed by a reasonable body of medical opinion. This supports the view earlier expressed by McNair J while addressing the jury in Bolam $v$ Friern Hospital Management

\footnotetext{
48 App. No.32555/96 (ECtHR) (October 19, 2005).

49 Shaun D. Pattinson, Medical Law and Ethics 2nd ed, (London: Sweet \&Maxwell Ltd, 2009) 119 .

50 Margaret Brazier, Medicine, Patient and the Law 3rd ed (London: Penguin, 2003) 110 referred in Pattinson ibid, p 123.

$51 \quad[1981] 1$ QB 432 at 443.

$5^{2}[1985]$ AC 871.
} 
Committee ${ }^{53}$ where he stated that "[a] doctor is not guilty of negligence if he has acted in accordance with a practice accepted as proper by a responsible body of medical man skilled in that particular art."

The views of the courts in these cases promote the concept of medical paternalism which prefers the opinion of the physician on what is best for the patient. This judicial approach has however witnessed a reverse in the more recent cases. In Pearce $v$ United Bristol Healthcare NHS Trust ${ }^{54}$ Lord Woolf observed, in a majority decision of the European Community Court, that "if there is a significant risk which would affect the judgment of a reasonable patient, then in the normal course it is the responsibility of a doctor to inform the patient of that significant risk." This position was approved by the House of Lords in Chester $v$ Afshar 55 where Lord Steyn stated that "[i]n modern law medical paternalism no longer rules and a patient has a prima facie right to be informed by a surgeon of a small, but well established, risk of serious injury as a result of surgery."

The preferred position, it is submitted, is that the physician should disclose to the patient, especially when the patient is conscious, all the medical procedure that would enable the patient to give an informed consent to a particular mode of treatment. A physician who assumes a paternalistic position in deciding what is good for the patient could be exposing himself/herself to a legal action that might arise from such conduct. There are reports in the advent of EVD outbreak suggesting that victims were quarantined at specific locations with little or no medical care. Some were reported to have escaped or attempted to escape from such confinements. ${ }^{56}$ This suggests that the victims were neither informed nor consented to such confinements. This constitutes infringement on the right of the victims to be informed by the healthcare providers.

\footnotetext{
53 [1957] 2 All ER 118 at 122.

54 [1999] PIQR 35 at 49.

55 [2004] UKHL 41 para 16.

56 'Ebola Patients Keep Escaping Liberian Hospitals' available at www.businessinsider .com/r-ebola-outbreak-stirs-anger-in-fragile-liberia (accessed 25 April 2015); See also 'Ebola Victim in Sierra Leone Escapes from Hospital' available at www.bellanaija.com/.../ ebola-victim-in-sierra-leone-escapes-from-hospit ( accessed 25 April 2015).
} 


\section{$7 \quad$ Patient Care and Right to Privacy and Confidentiality}

The word 'privacy' evolved from the Latin word 'privatus' meaning; apart from the state; peculiar to one's self; of or belonging to an individual; private'.57 In the simplest sense, 'right to privacy' connotes the right to control information about oneself. ${ }^{58}$ The right to privacy is the epicentre of all human freedoms and rights. It has become so important that it is a recurring provision in various international human rights instruments and constitutions of different countries. $^{59}$

The ICCPR contains provisions recognizing the right to privacy in article $17(1)$ which provides that " $\mathrm{n}] \mathrm{o}$ one shall be subjected to arbitrary or unlawful interference with his privacy, family, home or correspondence, nor to unlawful attacks on his honour and reputation". Similarly, the UN Convention on the Rights of the Child (CRC) provides in article 16(1) that "[n] o child shall be subjected to arbitrary or unlawful interference with his or her privacy, family, home or correspondence, nor to unlawful attacks on his or her honour and reputation".

At the national level, the Nigerian National Health Bill, 2014 provides in section 26 (1) that all information concerning a user, including information relating to his or her health status, treatment or stay in a health establishment is confidential. The constitutions of Nigeria, Sierra Leone, Guinea and Liberia all embody provisions on the protection of the right to privacy. Section 37 of the Nigerian Constitution, for instance, provides that the privacy of citizens, their homes, correspondence, telephone conversations and telegraphic communications is hereby guaranteed and protected.$^{60}$ The courts have accommodated various situations within the ambit of privacy. In Mark $v$ Seattle Times ${ }^{61}$ the Supreme of Washington held that the protectable interest in privacy generally involves at least four distinct types of invasion, namely: intrusion, disclosure, false light and appropriation. In relation to medical jurisprudence, the right of a woman to have an abortion has been upheld as a right to privacy. ${ }^{62}$ Similarly, the right to privacy has been adopted to justify the right of a minor to receive

\footnotetext{
57 VJ Samar, The Right to Privacy, Gays, Lesbians and the Constitution (Philadelphia, Temple University Press, 1991) 19.

$5^{8}$ JHF Shattuck, Rights of Privacy (USA, National Textbook Co 1977) 13.

59 Odunsi \& Nwafor (note 9 supra) 251.

6o See similar provisions under s 22 of the Sierra Leonean Constitution, arts 12 and 16 of Guinean and Liberian Constitutions respectively.

6196 WN 2nd 473, 635 P.2d 1081 (1981).

62 Roe v Wade 410 Us 113; R v Morgentaler [1988] 1 SCR 30.
} 
contraceptive. ${ }^{63}$ In Georgina Ahamefula v Imperial Medical Centre ${ }^{64}$ the Lagos High Court held that an unauthorized testing of the plaintiff's HIV status without consent was unlawful being an interference with an individual's privacy and encroachment on bodily integrity.

In the realm of medical law and ethics, the right to privacy translates to medical confidentiality. Confidentiality is one of the core tenets of medical practice. In the daily exercise of his functions, the physician receives private communications from the patient which the physician is bound to keep secret and in confidence. ${ }^{65}$ The need for medical confidentiality is recognised by various international instruments and medical ethics. The UN Committee on Economic, Social and Cultural Rights (CESCR) General Comment No 14 recognises that the need for the public to be informed should not impair the right to have personal health data treated with confidentiality. ${ }^{66}$ In other words, the patient's right to the preservation of health related information supersedes the public interest in this context. The World Medical Association Declaration of Lisbon on the Right of the Patient (Declaration of Lisbon) states that "[a]ll identifiable information about a patient's health status, medical condition, diagnosis, prognosis and treatment and all other information of a personal kind must be kept confidential even after death." ${ }^{\prime 67}$ The Convention on Human Rights and Biomedicine provides in article 10 that everyone has the right to respect for private life in relation to information about his or her health.

There are good reasons for insisting that information given to the physician by the patient be preserved. Firstly, is the right of the patient to medical autonomy. Secondly, are the likely consequences which unguarded disclosure of information may have on the patient. In cases of information which may expose the patient to stigmatization and discrimination, the patient could be treated as an outcast in the society. ${ }^{68}$ In Jansen Van Vuuren $v$ Kruger ${ }^{69}$ Harms AJA observed that:

There are in the case of [highly infectious disease] special circumstances justifying the protection of confidentiality. By the very nature of the disease, it is essential that persons who are at risk should seek medical

\footnotetext{
63 Carey v Population Services International 431 us 678 (1977).

64 Suit No.ID/16272000 (September 27, 2012). (Lagos State High Court).

65 See Odunsi \& Nwafor (note 59 supra) p 253.

66 General comment No 14 para 12.

67 Declaration of Lisbon para 8.

68 See Odunsi \& Nwafor (note 65 supra) pp 253-254.

$69 \quad 1983(4)$ SA $842(\mathrm{AD})$ at 31.
} 
advice or treatment. Disclosure of the condition has serious personal and social consequences for the patient. He is often isolated or rejected by others which may lead to increased anxiety, depression and psychological conditions.

Thirdly, is the need to afford the patient an opportunity to give health information freely and confidently to the physician. This is recognised by the British Medical Association guidelines where it is stated as follows:

Confidentiality is an essential requirement for the preservation of trust between patients and health professionals.... Patients should be able to expect that information about their health which they give in confidence will be kept confidential unless there is a compelling reason why it should not. There is also a strong public interest in maintaining confidentiality so that individuals will be encouraged to seek appropriate treatment and share information relevant to it. ${ }^{70}$

Fourthly, is the preservation of public interest which is assured when a patient seeks medical solution to ailments. This was recognised in $X v Y^{71}$ where Rose J said:

In the long run, preservation of confidentiality is the only way of securing public health; otherwise doctors will be discredited as a source of education, for future individual patients 'will not come forward if doctors are going to squeal on them. Consequently, confidentiality is vital to secure public as well as private health, for unless those infected come forward they cannot be counselled and self-treatment does not provide the best care.

$70 \quad$ See British Medical Association, 'Confidentiality and disclosure of health information tool kit' available at bma.org.uk/-/media/files/pdfs/.../ethics/confidentialitytoolkit_full.pdf (accessed 26 April 2015). See also Health Profession Council of South Africa Regulations 2006 Rule 13.

71 [1988] 2 All ER 648 (QBD) 653 para a-b. See also Hague v Williams [1962] 181 Atlantic Reporter $2 \mathrm{~d} 345$ at 349 where the court held that "[a] patient should be entitled freely to disclose his symptoms and condition to his doctor in order to receive proper treatment without fear that those facts may become public property. Only thus can the purpose of the relationship be fulfilled." 
Patient's privacy and confidentiality are often infringed by healthcare providers. Some acts of infringement include; (i) allowing access to patient's medical information to all hospital staff, including those not involved in the individual patient's care. A patient's health information should not be accessible to every healthcare giver in a healthcare center. A nurse whose role is to vaccinate a patient, should not ordinarily have access to that patient's private mental health records as the information is not relevant to the treatment being provided at that moment; (ii) Conducting medical examinations under public conditions. Privacy and confidentiality are crucial for patients seeking diagnosis and treatment of illnesses with which stigma is attached. ${ }^{72}$ The testing of persons for an infectious disease at public places and in the public glare infringes on patient's confidentiality.

The right to confidentiality of health information should not interfere with the patient's right to have access to his/her private health information. While a holder of private health information is prohibited from sharing that information with anyone who is not essential to providing health care to the patient, the holder must grant the patient access to their private health information upon the patient's request. Patients have the right to access their own health information and to control how such information is shared with other persons. The right to confidentiality of private health information, as well as the right to accessibility of private health information are patient's rights and should be respected by the healthcare providers. ${ }^{73}$ In Jansen Van Vuuren $v$ Kruger $^{74}$ a medical practitioner had disclosed the HIV status of his patient at a golf game after an explicit request by the patient to keep the information confidential to other health practitioners. The patient instituted proceedings claiming that the medical practitioner owed him a duty of confidentiality in relation to any information relating to the plaintiff/patient's medical conditions. The patient argued that he had suffered an invasion of his privacy and had been injured in his rights of personality. The medical practitioner contended that he had a social and moral duty to make the disclosure to the other health practitioners and that they had a reciprocal social and moral right to receive the information and apply due diligence when again dealing with or treating the plaintiff. Harms AJA held that AIDS is a dangerous condition, but that on its own does not detract from the right of privacy of the afflicted person, especially if

72 'Health and Human Rights Resource Guide' Harvard School of Public Health: Harvard University, available at http://hhrguide.org/wp-content/uploads/sites/25/2014/o3/ HHRRG-master.pdf (accessed 12 January 2015).

Ibid.

$74 \quad 19934 S A 842(A D)$. 
that right is founded in the doctor-patient relationship. A patient has the right to expect due compliance by the practitioner with his professional ethical standards: in this case the expectation was even more pronounced because of the express undertaking by the first defendant. The practitioners were not at risk and there was no reason to assume that they had to fear a prospective exposure. In consequence the judge concluded that the communication to the practitioners was unreasonable and therefore unjustified and wrongful. The court further emphasised that the duty of medical practitioners to respect the confidence of their patients is not merely an ethical duty but also a legal duty recognised by South African common law. In MS $v$ Sweden $^{75}$ the Court held that the protection of personal data, particularly medical data, is of fundamental importance to a person's enjoyment of his or her right to respect of private and family life. It was further held that respecting the confidentiality of health data is vital and crucial not only to the privacy of the patient but also to preserve his or her confidence in the medical profession and in the health services in general. In $Z v$ Finland ${ }^{76}$ the court emphasised that "[w]ithout such protection, those in need of medical assistance may be deterred from revealing such information of a personal and intimate nature as may be necessary in order to receive appropriate treatment and, even from seeking such assistance, thereby endangering their own health and, in the case of transmissible diseases, that of the community."

The non-observance of privacy and confidentiality in the screening and treatment of Ebola victims seemingly drove the infected persons underground and hence contributed to the spread of the disease in the affected countries. ${ }^{77}$ Screening was often done in public. Those who manifested symptoms of the disease were separated from others in public glare. ${ }^{78}$ The emaciated bodies of the victims were often shown on public television where they were isolated with very little medical attention and awaiting their eventual death. Even the dead were not spared this unnecessary exposure as men in medical protective gear were often shown conveying such bodies to the designated burial places. These conducts have adverse impacts on the families of such victims who are usually avoided as the disease is said to be transmissible by body contacts.

\footnotetext{
75 App. No.20837/92 (ECtHR) (August 27, 1997).

76 App. No.22009/93 (ECtHR) (February 25,1997) para 95.

77 'Guinea residents 'refusing' Ebola treatment' available at http://www.aljazeera.com/ news/africa/2014/og/guinea-residents-refusing-ebola-treatment-201492751955453636 .html (assessed 16 May 2015).

78 'Guinea: screening for Ebola at Conakry International Airport' available at http://www .who.int/features/2014/airport-exit-screening/en/ (accessed 20 May 2015).
} 
It is submitted that unless the infected persons in such situation of public health emergency are assured of their privacy and confidentiality, the victims will not be willing to voluntarily submit themselves for testing and treatment with the adverse consequence of clandestine even unintentional spreading of the disease.

8

Patient Care and Right to Non-discrimination

The UN Committee on Economic, Social and Cultural Rights defines discrimination as any "distinction, exclusion, restriction or preference or other differential treatment that is directly or indirectly based on the prohibited grounds of discrimination and which has the intention or effect of nullifying or impairing the recognition, enjoyment or exercise, on an equal footing, of covenant rights". ${ }^{79} \mathrm{~A}$ person is discriminated against when he is treated differently from others and in a manner that undermines his humanness. Discrimination is often associated with stigma. The quest by law to prevent discrimination is necessitated by the stigma attached to people who are given inhuman or degrading treatment. Stigma is a powerful and discrediting social label that radically changes the way individuals view themselves and are viewed as persons. ${ }^{80}$ People who are stigmatized are usually treated as outcast or shameful for some reasons and as a result are shunned, avoided, discredited, rejected, restrained or penalized. Reports have shown that the fear and stigma surrounding EVD infection results in people not seeking expert medical advice until they manifest the symptoms of the disease. The fear of being stigmatized or isolated may also cause people to conceal their illness. ${ }^{81}$ The panic surrounding the spread of the disease affected healthcare providers resulting in discrimination against patients suspected of being infected. ${ }^{82}$ The social hardship suffered by people

79 Committee on Economic, Social and Cultural Rights General Comment No 20, Nondiscrimination in Economic, Social and Cultural Rights (art 2, para 2) U.NDoc. E/C.12/GC/20 (2009).

8o S Iwuagwu, E Durojaiye et al, Human Rights and HIV/AIDS: Experience of people living with HIV/AIDS in Nigeria (Nigeria: CRH Publication 2001) 6.

81 International Federation of Red Cross and Red Crescent 'Battling fear and stigma over Ebola in West Africa-IFRC' available at http://www.ifrc.org/en/news-and-media/news -stories/africa/guinea/battling-fear-and-stigm (accessed 22 September 2014).

82 'Ebola hysteria causes discrimination against patients-health department' available at http://mg.co.za/article/2014-o8-30-ebola-hysteria-causing-discrimination-against-patients (accessed 22 September 2014). 
who are stigmatized is one of the reasons for the legal provision of the right to non-discrimination.

It should be emphasised that acts of discrimination offend international and national human rights instruments. The ICCPR provides in article 26 that "[a]ll persons are equal before the law and are entitled without any discrimination to the equal protection of the law. In this respect, the law shall prohibit any discrimination and guarantee to all persons equal and effective protection against discrimination on any ground such as race, colour, sex, language, religion, political or other opinion, national or social origin, property, birth or other status". In the same vein, article $2(2)$ of the ICESCR provides that the States Parties to the Covenant undertake "to guarantee that the rights enunciated in the present Covenant will be exercised without discrimination of any kind as to race, colour, sex, language, religion, political or other opinion, national or social origin, property, birth or other status". Also article 2 of the African Charter provides that: "Every individual shall be entitled to the enjoyment of the rights and freedoms recognized and guaranteed in the present Charter without distinction of any kind such as race, ethnic group, color, sex, language, religion, political or any other opinion, national and social origin, fortune, birth or other status".

The phrase 'or other status' has been interpreted by the CESCR General Comment No 20 to include health status. "Health status refers to a person's physical or mental health". ${ }^{83}$ The CESCR enjoins States parties to ensure that a person's actual or perceived health status is not a barrier to realizing the rights under the Covenant. ${ }^{84}$ The Constitutions of Nigeria, Sierra Leone, Liberia and Guinea also embody provisions against discrimination. ${ }^{85}$

It is observed in the General Comment that the protection of public health is often cited by states as a basis for restricting human rights in the context of a person's health status. However, many such restrictions are discriminatory, for example, when HIV status is used as the basis for differential treatment with regard to access to education, employment, healthcare, travel, social security, housing and asylum. ${ }^{86}$ The courts in South Africa have similarly held that

83 General Comment No. 20 para 33.

84 Ibid.

85 See ss 42 and 27 of the Nigerian and Sierra Leonean Constitutions respectively, as well as arts 18 and 8 of the Liberian and Guinean Constitutions respectively.

86 General Comment No 20 para 33 . 
discrimination on ground of health status is unlawful. In Hoffmann $v$ South African Airways ${ }^{87}$ Ngcobo J said:

Society has responded to [the plight of those living with HIV] with intense prejudice. They have been subjected to systemic disadvantage and discrimination. They have been stigmatized and marginalised.... Society's response to them has forced many of them not to reveal their HIV status for fear of prejudice. This in turn has deprived them of the help they would otherwise have received ... any discrimination against them can, to my mind, be interpreted as a fresh instance of stigmatization and I consider this to be an assault on their dignity. The impact of discrimination on HIV positive people is devastating. It denies them the right to earn a living. For this reason, they enjoy special protection in our law.

Patients should not be discriminated against in the occasion of public health emergency. What is needed is the balancing of the interests of the patient with those of the wider society as stated by the Indian court in $M X$ of Bombay Indian Inhabitant $v M / s$ ZY and another ${ }^{88}$ as follows:

Taking into consideration the widespread and present threat of this disease [HIV/AIDS] in the world in general ... the State cannot be permitted to condemn the victims ... many of whom may be truly unfortunate, to certain ... death. It is not in the general public interest and is impermissible under the Constitution. The interests of the [victims] ... and the interests of the society will have to be balanced in such a case.

In Hamel $v$ Malaxos ${ }^{89}$ it was held that a physician must not deny treatment to patients because their medical condition may put the physician at risk. If a patient poses a risk to the physician's health or safety, the physician should take all available steps to minimise the risk before providing treatment or making other suitable alternative arrangement for providing treatment.

872001 (1) SA 1 (CC) para 28. See also Allpass v Mooikloof Estates (Pty) Ltd t/a Mooikloof Equestrain Centre 2011 (2) SA 638 (LC).

$88 \quad$ AIR 1997 (Bombay) 406 at 431.

89 25, Nov.1993, No:730-32-0oo37929, small claims court Joliette (Unreported) available at www.anilaggrawal.com $>$... Reviews $>$ TechnicalBooks (accessed 11 February 2015); See also Stanislaw Frankowski, Legal responses to AIDS in comparative perspective 1st ed (Netherlands: Imprint of Brill Academic Publishers,1998) 87. 
This decision perhaps justifies the wearing of protective gear by healthcare providers attending to the EVD patients. Though there is always the need for the protection of the wider society as suggested by the above decisions, there is no justification for abandoning such patients or confining them in their homes or in designated healthcare centres without medical facilities and as such condemning them to a certain death.

Patient Care and Freedom from Torture and Cruel, Inhuman, and Degrading Treatment

Article 7 of the ICCPR provides that no one shall be subjected to torture or to cruel, inhuman or degrading treatment or punishment. In particular, no one shall be subjected without his free consent to medical or scientific experimentation. Similarly, article 5 of the Un Universal Declaration of Human Rights, 1948 provides that no one shall be subjected to torture or to cruel, inhuman or degrading treatment or punishment. At the regional level, the Protocol to the African Charter on Peoples' and Human Rights on the Right of Women in Africa under article 4(1) prohibits all forms of exploitation, cruel, inhuman or degrading punishment and treatment. There are also provisions under the constitutions of Nigeria, Sierra Leone, Guinea and Liberia respectively on similar terms as the above international instruments. ${ }^{90}$

In Keenan v United Kingdom ${ }^{91}$ the European Court of Human Rights stated that ill-treatment must attain a minimum level of severity if it is to fall within the scope of Article $3 .{ }^{92}$ The assessment of this minimum is relative: it depends on all the circumstances of the case, such as the duration of the treatment, its physical and/or mental effects and, in some cases, the sex, age and state of health of the victim.

The denial of healthcare to incarcerated persons even on account of commission of crime has been held by the courts to amount to torture, cruel and inhuman treatment. This was the position unanimously adopted by the European Court in Hurtado $v$ Switzerland ${ }^{93}$ where the court held that the State's

\footnotetext{
9o See ss 34(1)(a) and 20 of Nigerian and Sierra Leonean Constitutions respectively, arts 6 and $21(\mathrm{e})$ of Guinean and Liberian Constitutions respectively.

91 App. No. 27229/95 (ECtHR) (April3, 2001).

92 Article 3 of the European Convention on Human Rights similarly prohibits torture, inhuman and degrading treatment.

93 App. No. 17549/9o (ECtHR) (January 28, 1994).
} 
failure to provide timeous medical treatment to the detained applicant was an act of inhuman and degrading treatment.

Such denial of medical care could also constitute an infringement on the right to healthcare of the incarcerated person. In Festus Odafe \& Others $v$ Attorney General of the Federation and Others ${ }^{94}$ the applicants who were detainees at the Kirikiri maximum security prison in Lagos contracted HIV while in detention and were denied the right to treatment by the prison officials. In an action to enforce their fundamental rights under the Nigerian Constitution and the African Charter, the court held that the denial of treatment to the four prisoners violated section 8 of the Nigerian Prison Act of 1972 and article 16 of the African Charter. Nwodo J of the Federal High Court of Nigeria re-emphasised the obligation of the government in the enforcement of socio-economic rights, especially the right to health, under the African Charter as follows:

The government of this country has incorporated the African Charter on Human and Peoples' Rights Cap 10 as part of the law of the country.... The Charter entrenched the socio-economic rights of a person. The Court is enjoined to ensure the observation of these rights. A dispute concerning socio-economic rights such as the right to medical attention requires the Court to evaluate state policy and give judgment consistent with the Constitution. I therefore appreciate the fact that the economic cost of embarking on medical provision is quite high. However, the statutes have to be complied with and the state has a responsibility to all the inmates in prison, regardless of the offence involved, as in the instant case where ... the applicants ... have been in custody for not less than two years suffering from an illness. They cannot help themselves even if they wanted to because they are detained and cannot consult their doctor. I therefore ... order the authorities ... [to] relocate the applicants after the precondition has been complied with, to a hospital in accordance with section 8 of the Prison Act. ${ }^{95}$

Similar decisions have been reached by the African Regional Courts. The decision of the African Commission on Human and Peoples' Rights in International Pen and Others (on behalf of Ken Saro Wiwa) $v$ Nigeria ${ }^{96}$ lends credence to this assertion. In that case, Saro Wiwa, a writer and environmental rights activist, together with eight others, were sentenced to death for their social

\footnotetext{
94 (2004) AHRLR 205 (NgHC2004).

95 Ibid. paras 37-39.

96 (2000) AHLR 212(ACHPR 1998).
} 
crusade activities in Ogoni land in the Niger Delta region of Nigeria. While in detention awaiting execution, Saro Wiwa's health deteriorated to the point that he required medical attention. The Nigerian government denied him access to treatment in spite of the prison doctor's recommendations. The African Commission held that Saro Wiwa's right to health under article 16 of the African Charter was violated by the Nigerian government. In arriving at this decision, the Commission stated as follows:

The responsibility of the government is heightened in cases where an individual is in its custody and therefore someone whose integrity and well-being is completely dependent on the actions of the authorities. The state has a direct responsibility in this case. Despite requests for hospital treatment made by a qualified prison doctor, these were denied to Ken Saro Wiwa, causing his health to suffer to the point his life was endangered.... This is a violation of article $16 .{ }^{97}$

Similarly, in Purohit \& More $v$ The Gambia ${ }^{98}$ the Commission emphasised that the:

Enjoyment of the human rights to health as it is widely known is vital to all aspects of a person's life and well-being, and is crucial to the realization of all the other fundamental human rights and freedoms. This right includes the right to health facilities, access to goods and services to be guaranteed to all without discrimination of any kind.

The victims of Ebola were reportedly confined in their homes or at designated health centres without quality care, functioning water supply and no air conditioning facilities. The families of the patients were mostly responsible for their care and provision of essential needs of the patients. ${ }^{99}$ In Keenanv United

97 Article 16 of the ACH PR provides that "(1) Every individual shall have the right to enjoy the best attainable state of physical and mental health. (2) State parties to the present Charter shall take the necessary measures to protect the health of their people and to ensure that they receive medical attention when they are sick."

98 (2003) AHLRA 96 at 108.

99 Ebola Patients Abandoned, Health Team Down Tools-Health-Nairaland' available at http://www.nairaland.com/1862229/ebola-patients-abondoned-health-team (accessed 9 September 2014); See also 'Nigeria Hasn’t Given Priority to Ebola Treatment, Abandons Nano Silver Treatment' available at http://www.nursingworldnigeria.com/2014/o8/nigeria -hasn-rsquo-t-given-priority-to-e (accessed 9 September 2014). 
King dom $^{100}$ the European Court had emphasised that persons in custody are in a vulnerable position and that the authorities are under a duty to protect them. There is therefore an enhanced responsibility on the governments of the affected countries to ensure that the health need of the victims of EVD who are quarantined or confined at designated centres are fully addressed. Failure on the part of the government to provide medical care for EVD patients in such confinements constitute torture and cruel, inhuman, and degrading treatment, and also an infringement of the right to healthcare of the victims.

\section{Limitation of Patients' Rights}

The healthcare provider is usually confronted with the delicate choice of preservation of self and the wider society as against the interests of the patient in times of public health emergency. This is the kind of dilemma which a physician is faced when attending to a patient with a virulent disease like Ebola. Although the physician is enjoined by the ethics of his profession to prefer the interests of the patient above self-interest, there are rooms created by law and ethics for derogation from those obligations in the interests of the wider society.

In the area of maintaining of confidentiality, for instance, a physician's obligation to a patient's confidentiality is not absolute. Situations do arise where the harm in maintaining confidentiality is greater than the harm brought about by divulging confidential information. The guiding question for the physician in such a dilemma is: will lack of this specific information about this patient put a specific identifiable person at a high risk of serious harm? ${ }^{101}$ The answer to this question which the physician provides subjectively guides his decision in a given situation. ${ }^{102}$

Historically, the physician's public interest role was in the control of serious crimes. Avory J alluded to this in 1914 as follows:

There are cases where the desire to preserve [the confidential relation which exists between a medical man and his patient] must be

\footnotetext{
100 App. No. 27229/95 (ECtHR) (April 3, 200).

101 Jessica De Bord, Wylie Burke \& Denise M. Dudzinski, 'Confidentiality' Ethics in Medicine' University of Washington School of Medicine, available at http://depts.washington.edu/ bioethx/topics/confiden.html (accessed 27 April 2015).

102 Odunsi \& Nwafor (note 68 supra) 258.
} 
subordinated to the duty which is cast on every good citizen to assist in the investigation of serious crime. ${ }^{103}$

The modern medical practice has, however, recognised that it is generally ethically justified to disclose a diagnosis to the public health authorities if the risk to the public has the following features: the risk is high in probability; the risk is serious in magnitude; and the risk relates to an identifiable individual or group. ${ }^{104}$

Ethical issues apart, there are various statutory instruments that limit the human rights of the patient in preference for the protection of the public. Article 9(1) of the ICCPR, for instance, provides that: "Everyone has the right to liberty and security of person. No one shall be subjected to arbitrary arrest or detention. No one shall be deprived of his liberty except on such grounds and in accordance with such procedure as are established by law". Similarly, article 6 of the African Charter provides that: "Every individual shall have the right to liberty and to the security of his person. No one may be deprived of his freedom except for reasons and conditions previously laid down by law." The law generally recognised that liberty of a person could be restricted where a crime has been committed. In the area of healthcare, the restriction of liberty of the patient could take the form of quarantine in order to prevent the spread of an infectious disease during public health emergency. Such a restriction is justified if it complies with the protocol laid down under international human rights law.

International human rights law, as observed by Human Rights Watch, has set down a bench-mark that states should observe for the quarantining of persons in times of public health emergency as follows:

$[\mathrm{R}]$ estrictions on human rights in the name of public health or public emergency meet requirements of legality, evidence-based necessity, and proportionality. Restrictions such as quarantine or isolation of symptomatic individuals must, at a minimum, be provided for and carried out in accordance with the law. They must be strictly necessary to achieve a legitimate objective, the least intrusive and restrictive available to reach the objective (sic), based on scientific evidence, neither arbitrary nor discriminatory in application, of limited duration, respectful of human dig-

103 Birmingham Assizes, I December 1914, (1914) 78 JP 604.

104 Erika Blacksher, 'Public Health Ethics' Ethics in Medicine, University of Washington School of Medicine, available at https://depts.washington.edu/bioethx/topics/public.html (accessed 27 April 2015). 
nity, and subject to review. When quarantines are imposed, governments have absolute obligation to ensure access to food, water, and healthcare. ${ }^{105}$

The quarantine imposed on the victims of EVD and others by the respective governments in the affected countries did not comply with the international protocol as set down above. Victims were reported to have been confined in their homes and healthcare centres with little or no existing health facilities. ${ }^{106}$ Such confinement, where it fails to satisfy the basic international protocol, though could be seen as protecting the societal interests, constitutes an infringement of the individual's right to healthcare.

At the national level, the constitutions of Nigeria, Sierra Leone, Guinea and Liberia respectively, recognise limitations to the human rights provisions. Section 45(1) of the Nigerian Constitution is instructive in that regard. It provides as follows:

Nothing in sections $37,38,39,40$ and 41 of this Constitution shall invalidate any law that is reasonably justifiable in a democratic society

- (a) in the interest of defence, public safety, public order, public morality or public health; or

- (b) for the purpose of protecting the rights and freedom of other persons. ${ }^{107}$

The courts have given judicial support to these constitutional provisions which are aimed at the protection of the overriding interests of the society. In Medical and Dental Practitioners Disciplinary Tribunal v Okonkwo ${ }^{108}$ Ayoola JSC, while recognising a patient's autonomy founded on the constitutionally guaranteed right to liberty, privacy and freedom of thought, conscience and religion, held that those can be eroded:

$[\mathrm{w}]$ here they impinge on the right of others or where they put the welfare of the society or public health in jeopardy. The sum total of the rights of privacy and of freedom of thought, conscience and religion which an individual has ...

105 'West Africa: Respect Rights in Ebola Response| Human Rights Watch' available at http://www.hrw.org/news/2014/og/15/west-africa-respect-rights-ebola-response (accessed 22 September 2014).

106 Ebola virus disease' available at http://en.wikipedia.org/wiki/Ebola_virus_disease (accessed 9 September 2014).

107 See also s 15 of the Sierra Leonean Constitution, Arts 24 and 11 of the Guinean and Liberian Constitutions respectively.

108 [2001] 7 NWLR (pt 711) 206 SC at 244. 
is that an individual should be left alone to choose a course for his life, unless a clear and compelling overriding state interest justifies the contrary.

In Soobramony v Minister of Health, KwaZulu-Natal ${ }^{109}$ the South African Constitutional Court alluded to the need to spread scarce state resources to benefit the majority of those in need and not just an individual or a few individuals in the enforcement of socio-economic rights. This again reflects the balancing of public interest with that of the individual.

There is nothing wrong in principle with subjecting a patient's right to the overriding consideration of the safety of the society as a whole in times of public health emergency as the individual also needs a safe community to survive. It must however always be borne in mind that the rights of a patient, whether seen from the ethical or legal perspective, bear a semblance of personal property which adds value to the person's existence and quality of life. Any derogation from such rights in preference for public interests should as such adhere strictly with the specified protocol contained in the enabling law or rules of ethics to attain some level of legitimacy.

The healthcare providers have legal and ethical duties to address a patient's needs that fall within the healthcare provider's scope of practice even in times of public health emergency. Refusing to do so is not consistent with the ethical principle of beneficence. Admittedly, the healthcare providers need to stay alive in order to attend to the needs of the patient especially when confronted with life threatening and infectious disease such as EVD, emphasis should not however be unduly placed on self-preservation and welfare of the healthcare providers over those of the patients. Doing otherwise will be acting contrary to the medical ethics espoused by the Hippocratic Oath.

The preservation of the patients' interests and protection of their rights are however not absolute demands on the healthcare providers and the state. There is always the issue of overriding public interests which could justify the curtailment of such rights. Both international and national instruments that provide for the rights of the patient also permit such derogation for the protection of public interests. It is however important that necessary protocols be followed where the patients' rights are curtailed. For instance, the disclosure of the patient's confidential information by the healthcare provider must be discreetly done and only in situations where there is an identifiable person who is

$109 \quad 1998(1)$ SA $765(\mathrm{CC})$. 
at risk of being infected and the patient has declined to make such disclosure or grant consent to the healthcare provider to disclose.

The healthcare providers and the State are under ethical and legal obligations respectively to ensure that those in quarantine are fully informed of the reason for placing restrictions on their movement. They should be provided with adequate medical facilities and other amenities to keep them in good health. A blanket lock down of the entire community without food or water and medical facilities under a public health emergency cannot be justified either in law or ethics. Quarantined persons under a public health emergency should always be made to appreciate the essence which is primarily to provide them with quick medical solution and to prevent the spreading of the infectious disease. 